\title{
Ontogenetic and seasonal changes in the feeding habits and trophic levels of two small pelagic fish species
}

\author{
David Costalago*, Joan Navarro, Ignacio Álvarez-Calleja, Isabel Palomera
}

Institut de Ciències del Mar (ICM-CSIC), Passeig Marítim de la Barceloneta 37-49, 08003 Barcelona, Spain

\begin{abstract}
We investigated ontogenetic and seasonal changes in the feeding ecology of 2 small pelagic fish species, the European anchovy Engraulis encrasicolus and the European pilchard Sardina pilchardus in the Gulf of Lions (NW Mediterranean). By analysing the stable isotopes $\delta^{13} \mathrm{C}$ and $\delta^{15} \mathrm{~N}$, we determined the seasonal variation in the food sources and in the trophic level of these species, and we examined dietary shifts during development. The results of these investigations provided estimates of the diets of both species. We compared the values observed during different seasons (summer, autumn and winter) and at different developmental stages (latelarvae, juveniles and adults) for both species, together with the values of potential groups of prey (microplankton, cladocerans, copepods and appendicularians). Late-larvae preferred to feed on microplankton, although differences in the diet appeared after metamorphosis. Cladocerans were usually the preferred prey when available (summer), and appendicularians were the preferred prey in autumn. During the winter, the diets seemed to be more heterogeneous. Different feeding behaviours between the late-larvae of the 2 species were the most likely reason for the slightly different trophic levels found in the present study. This research demonstrates that studies with stable isotopes can furnish an alternative and/or complementary method for determining the diet of small pelagic fishes over extended periods and provides comprehensive knowledge of the functioning of the pelagic ecosystem.
\end{abstract}

KEY WORDS: Engraulis encrasicolus · Sardina pilchardus · Stable isotopes · NW Mediterranean · Trophic ecology $\cdot$ Microplankton $\cdot$ Copepods $\cdot$ Appendicularians $\cdot$ Cladocerans

Resale or republication not permitted without written consent of the publisher

\section{INTRODUCTION}

An understanding of the primary ecological processes in marine ecosystems, such as variation in food sources, trophic transfer through the food web and nutrient cycling, is fundamental for relating ecosystem functioning to management. In this context, the description of the trophic ecology of marine organisms is vital to determine the intrinsic factors that control their distribution, abundance, and, ultimately, their function within the ecosystem. Fishes have developed a wide variety of feeding-related structures (e.g. gill rakers, pyloric caeca, or teeth) and behaviours (e.g. filter feeding vs. particulate feeding) that may undergo modifications through ontogeny or season (Gerking 1994), with diverse ecological implications. Many studies have addressed the trophic roles of both top and bottom species of the food web, i.e. marine predators and plankton communities, respectively (Hunter \& Price 1992, Rice 1995, Pace et al. 1999), and, among these studies, some have focused on a group that is particularly important ecologically: the small pelagic fishes (Bakun 1996, Cury et al. 2000, Palomera et al. 2007).

Small pelagic fish are essential elements of marine ecosystems owing to their significant biomass at intermediate levels of the food web (Cury et al. 2000, Palomera et al. 2007). Pelagic fish play a significant 
role in connecting the lower and upper trophic levels (Cury et al. 2000). Their massive populations, which exert a huge pressure on zooplankton and, at the same time, are the main food for many species, may vary greatly in size under intensive exploitation or following changes in productivity. Therefore, fluctuations in small pelagic populations owing to fishing or natural factors modify the structure and functioning of the marine ecosystem (e.g. Cury et al. 2000, Shannon et al. 2000, Daskalov 2002). The significant abundance and success of pelagic fish in upwelling areas have been attributed to the flexibility of their feeding behaviour (van der Lingen et al. 2009). Pelagic fish have also been identified as important groups in many ecosystems (Libralato et al. 2006), e.g. in upwelling areas, where they exhibit a 'waspwaist' flow control (Cury et al. 2000). Therefore, the interactions among different populations of small pelagic fishes can also be strongly influenced by regime climatic shifts and can have strong impacts on fisheries (e.g. Klyashtorin 1998, Rodríguez-Sanchez et al. 2002).

Low trophic-level species are directly influenced by the remarkable environmental differences between seasons (Calbet et al. 2001). The populations of small pelagic fish may be affected by any environmental change that influences the plankton community, which is the basis of the diet of these fishes. In fact, the seasonal unevenness of oceanographic parameters (i.e. salinity, fluorescence and, most importantly, temperature) and of river runoff has been shown to have important effects on the biology and viability of these fish populations (Lloret et al. 2001, 2004). The early life stages (i.e. larvae and juveniles) are especially sensitive to such effects (Govoni 2005, Ruiz et al. 2006, Costalago et al. 2011). Several species of small pelagic fish co-occur in the Mediterranean Sea. Unquestionably, the European anchovy Engraulis encrasicolus and the European sardine Sardina pilchardus are the most relevant of these species in terms of both biomass and fishery catches (Palomera et al. 2007). These 2 small pelagic fish are also key species at mid-trophic levels in the Mediterranean Sea (Coll \& Libralato 2012). E. encrasicolus was found to be a key species in the North Adriatic (Coll et al. 2007, Barausse et al. 2009) and in the Aegean Sea (Tsagarakis et al. 2010). On the contrary, in the NW Mediterranean, $S$. pilchardus is among the leading keystone species and is also considered to exhibit 'wasp-waist' trophic control (Coll et al. 2006, Palomera et al. 2007, Navarro et al. 2011). Small pelagic fish are the most vulnerable to any environmental shift among fish species (Coll et al. 2008). At the same time, they are the main constituents of the diet of several pelagic, demersal and apical species (e.g. Coll et al. 2006, Palomera et al. 2007, Navarro et al. 2009).

A significant number of studies on the ecology of anchovy and sardine in the Mediterranean Sea have been conducted (see reviews by Palomera et al. 2007, Morello \& Arneri 2009), but relatively few of these studies address dietary composition. Previous papers that included dietary information focussed on larval stages of Engraulis encrasicolus and Sardina pilchardus (Conway et al. 1998, Tudela et al. 2002, Catalán et al. 2010, Morote et al. 2010), the adults of E. encrasicolus (Tudela \& Palomera 1997, Plounevez \& Champalbert 2000), or the juveniles and adults of $E$. encrasicolus (Borme et al. 2009). However, none of the previous works, that, in addition, have usually been limited in temporal resolution, included data about sardines, except that of Morote et al. (2010), and they studied only larvae $<1.6 \mathrm{~cm}$ in total length. A more comprehensive understanding of the trophic dynamics of assemblages of small pelagic fish from a seasonal and ontogenetic perspective is therefore essential to highlight the important role of these populations within the marine ecosystem. The present study intends to provide this necessary knowledge more comprehensively by gathering and analyzing data from different seasons and life stages of these 2 pelagic species for the first time in the Mediterranean.

All previous studies on the trophic ecology of these small pelagic fish species have been based on the direct analysis of stomach contents (Tudela \& Palomera 1997, Conway et al. 1998, Plounevez \& Champalbert 2000, Borme et al. 2009, Morote et al. 2010). This approach involves implicit methodological errors because it cannot accurately quantify the importance of prey items that are readily digested and because it does not identify the prey items that are actually assimilated following ingestion. The stable isotope approach can augment conventional means of dietary analysis because stable isotopes reflect timeintegrated dietary records and present a perspective on trophic dynamics that involves a more substantial time period than the analysis of stomach contents can provide (Polunin \& Pinnegar 2008). Therefore, stable isotope analysis yields information that cannot always be obtained from direct observation and can support hypotheses about the developmental changes in the feeding strategies of a species and about species interactions because these hypotheses are based on data about assimilated food rather than ingested food. In fish, the stable isotope values of muscular tissue integrate dietary information 


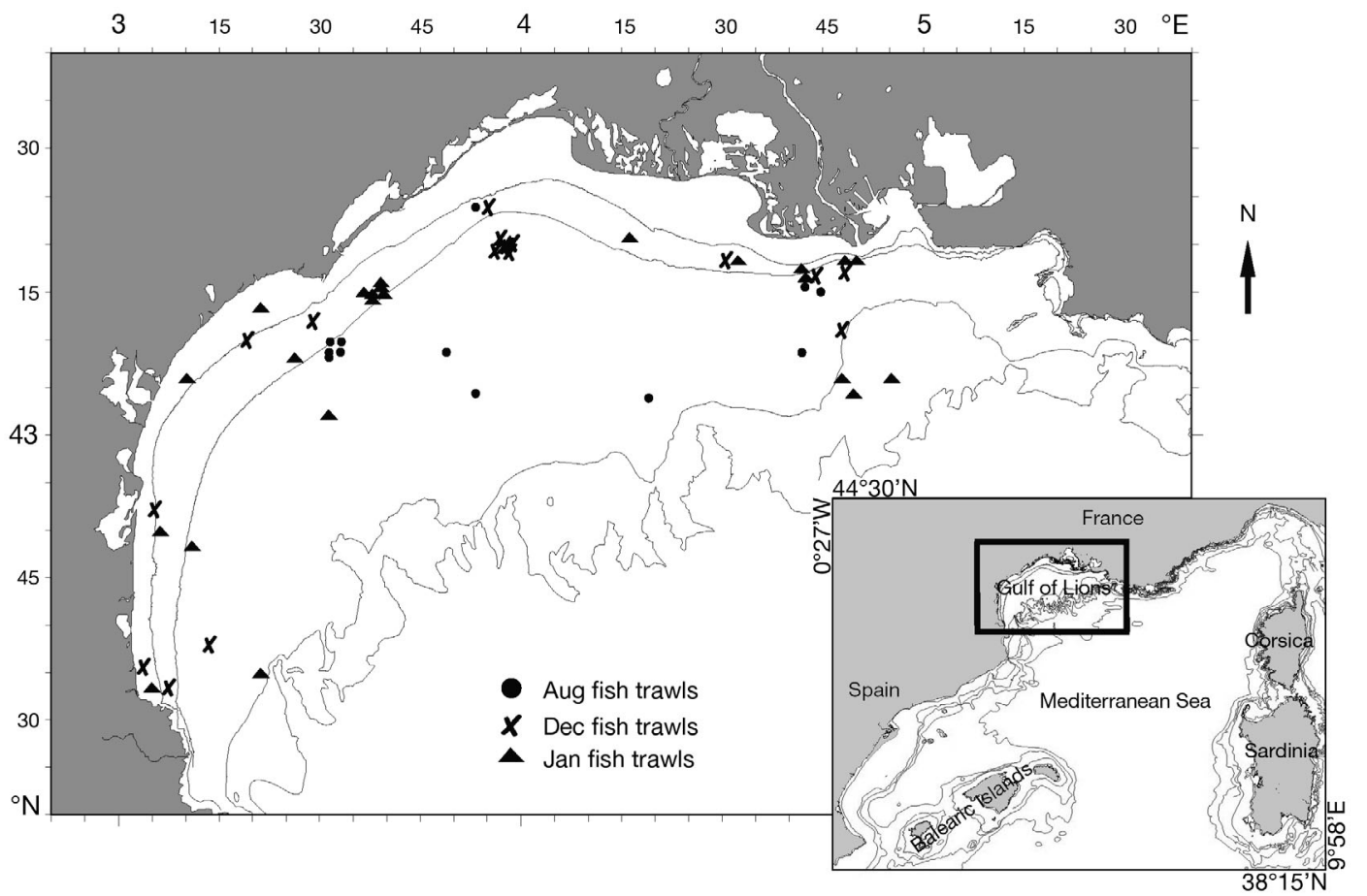

Fig. 1. Study area (Gulf of Lions, NW Mediterranean), indicating fish and plankton sampling locations. The bathymetric lines correspond to depths of 20,50, 100 and $200 \mathrm{~m}$

between 40 and $80 \mathrm{~d}$ prior to sampling (Bode et al. 2007, Buchheister \& Latour 2010). Stable isotopes of nitrogen $\left(\delta^{15} \mathrm{~N}\right)$ are indicators of trophic positions because consumers are predictably enriched in $\delta^{15} \mathrm{~N}$ relative to their food (Post 2002, Vanderklift \& Ponsard 2003). Stable carbon isotope values $\left(\delta^{13} \mathrm{C}\right)$ give information on primary production and are useful for tracing the origin of the prey consumed (Vander Zanden et al. 1999, Pinnegar \& Polunin 2000). Furthermore, by combining stable isotope values for consumers and their prey, powerful isotopic mixing models can be applied to obtain estimates of the relative contribution of each potential prey item to the diet of the consumer (e.g. stable isotope analysis in $\mathrm{R}$ [SIAR] isotopic mixing model; Parnell et al. 2010). These models add useful information to investigations of food selectivity and can be used to complement data from stomach content analysis (Peterson 1999, Lin et al. 2007, Tripp-Valdez \& ArreguínSánchez 2009).

Flaherty \& Ben-David (2010) pointed out that there are limitations in the use of isotopic mixing models because of the important differences in isotope values that can be found if there is spatial heterogeneity, so that habitat-derived variation in consumers' isotopes would be mistaken as diet variation in resource isotope values. Since populations of Engraulis encrasicolus and Sardina pilchardus in the Gulf of Lions are widespread and homogenously distributed over the whole of the continental shelf and therefore feeding on the same available resources, we could assume that this limitation would not be of great influence in our case.

The present study uses $\delta^{13} \mathrm{C}$ and $\delta^{15} \mathrm{~N}$ values as indicators of the trophic relationships between Engraulis encrasicolus and Sardina pilchardus for different age groups (late-larvae, juveniles and adults) during different seasons (summer, autumn and winter) and therefore under different environmental conditions. The study investigates seasonal and ontogenetic changes in the food sources and trophic levels of these species, and it examines possible dietary shifts during development. These analyses yield estimates of the diet composition of both species. All of these findings are important because they can supply the knowledge needed to fill current information gaps existing in both experimental and direct observational studies and allow improved management of fish stocks.

\section{MATERIALS AND METHODS}

\section{Study area and sample collection}

The present study was conducted in the Gulf of Lions (Fig. 1), one of the most productive areas of the NW Mediterranean (Salat 1996). In terms of biomass, 
it is also the most important area of the Mediterranean for small pelagic fish species (Barangé et al. 2009). During 3 different oceanographic cruises on board the RV 'L'Europe' (IFREMER, France), we collected late-larvae, juveniles and adults of Engraulis encrasicolus and Sardina pilchardus. The standard length ranges considered to classify the individuals within these groups were: for late-larvae $2.0-3.5 \mathrm{~cm}$ for E. encrasicolus and $2.5-4.0 \mathrm{~cm}$ for $S$. pilchardus, for juveniles $3.6-8.5 \mathrm{~cm}$ for E. encrasicolus and $4.1-10.5 \mathrm{~cm}$ for $S$. pilchardus and for adults 8.6-12 cm for E. encrasicolus and $10.6-14 \mathrm{~cm}$ for $S$. pilchardus. All individuals were considered as adults when they reached the minimum length at first maturity observed during the cruises. The first cruise was conducted during autumn (12 to 21 December 2007), the second cruise was conducted during summer (21 to 29 July 2008) and the third was conducted during winter (11 to 27 January 2009). All specimens were caught with a pelagic trawling net equipped with a small-mesh codend (mesh length: $5 \mathrm{~mm}$; ISO 1107) and towed at an average speed of 3.6 knots over a 30 to $40 \mathrm{~min}$ period. The samples were immediately frozen $\left(-20^{\circ} \mathrm{C}\right)$ after sorting on board.

During each season, plankton samples were collected at the same sites where the pelagic trawls were made. Sampling was done at 16 plankton stations in summer, 15 in autumn and 13 in winter using a standard WP2 net with a mesh size of $200 \mu \mathrm{m}$ and a scaled-down WP2 net with a mesh size of $53 \mu \mathrm{m}$. The WP2 net sample was sieved through a $3000 \mu \mathrm{m}$ plankton mesh to obtain the 200 to $3000 \mu \mathrm{m}$ mesozooplankton fraction and the scaled-down WP2 net was sieved through a $200 \mu \mathrm{m}$ plankton mesh to obtain the 53 to $200 \mu \mathrm{m}$ microplankton fraction. All plankton samples were split with a Motoda plankton splitter (Motoda 1959). One-half of each sample was preserved in buffered $4 \%$ formaldehyde-seawater solution for subsequent qualitative analyses of plankton community composition, whereas the other half was frozen $\left(-20^{\circ} \mathrm{C}\right)$ on board for biomass measurements and stable isotopic determination. Qualitative analysis of plankton was performed in the laboratory, and individuals were identified to the lowest taxonomical level possible under a stereomicroscope (Leica MZ12) with a magnification of up to $100 \times$. The mesozooplankton samples were analysed in aliquots representing about $10 \%$ of the sample and repeated until counting at least 400 copepods in each; additional subsamples were also taken for any other abundant organism (i.e. cladocerans during summer). Microplankton samples were subsampled differently: 1 to $2 \%$ of the original volume was analysed to estimate the presence of nauplii, dinoflagellates, ciliates and diatoms; small copepods (mainly copepodites) were analysed in volumes sufficient to count at least $400 \mathrm{in}$ dividuals. The number of individuals of each identified taxon and abundances (ind. $\mathrm{m}^{-3}$ ) were calculated.

\section{Stable isotope analysis}

A portion of dorsal muscle (without skin) was extracted from each individual (late-larvae, juveniles and adults). Muscle has been defined as the most appropriate tissue to analyse stable isotope in fish (Sweeting et al. 2005). Plankton samples from each season were defrosted in the laboratory, pooled together and sorted into different potential prey groups (microplankton, copepods and appendicularians in all the seasons, and also cladocerans in summer) which were selected according to previous studies of stomach contents (Morote et al. 2010 for larvae, D. Costalago unpubl. data for juveniles, Plounevez \& Champalbert 2000 for adults).

All fish and plankton samples were freeze-dried, powdered, and 0.9 to $1.0 \mathrm{mg}$ of each sample was packed into tin capsules. The samples were then oxidised with $\mathrm{CuO}$ and $\mathrm{CO}_{3} \mathrm{O}_{4} / \mathrm{Ag}$ at approximately $900^{\circ} \mathrm{C}$ in a Flash EA 1112 Elemental Analyser coupled with a pyrolyser TC-EA and a gas bench through a Conflo III Finnigan MAT interface. $\mathrm{NO}_{\mathrm{x}}$ was reduced with $\mathrm{Cu}$ at $680^{\circ} \mathrm{C}$. The combustion products $\mathrm{N}_{2}$ and $\mathrm{CO}_{2}$ were introduced into a Delta C Finnigan MAT mass spectrometer through an $\mathrm{MgClO}_{4}$ drying column. The isotope ratio mass spectrometry facility at the Serveis Científico-Tècnics of the University of Barcelona (Spain) applies international standards, generally run for every 12 samples: IAEA CH7 (87\% of C), IAEA CH6 (42\% of C) and USGS 24 (100\% of C) for $\delta^{13} \mathrm{C}$ and IAEA N1 and IAEA N2 (with $21 \%$ of N) and IAEA $\mathrm{NO}_{3}(13.8 \%$ of $\mathrm{N})$ for $\delta^{15} \mathrm{~N}$.

The $\delta^{13} \mathrm{C}$ values were corrected for the effect of lipids both in fish and prey samples following Logan et al. (2008). This procedure reduces the time and uncertainty associated with lipid extraction procedures, and it improves the estimates of dietary proportions derived from stable-isotope mixing models (Phillips \& Gregg 2001, Logan et al. 2008).

\section{Isotopic mixing model}

To estimate the diet composition at each age (latelarvae, juveniles and adults) during each season (summer, autumn and winter) we applied a Bayesian 
model in SIAR 4.1.1 (Stable Isotope Analysis in $\mathrm{R}$ 2.12.2). This model runs under the free software $R(R$ Development Core Team 2009). The model allows the inclusion of sources of uncertainty. In particular, the variability in the isotope signatures (mean and standard deviation) of prey species can be incorporated into the model (Parnell et al. 2010). SIAR uses Markov-chain Monte Carlo modelling, takes data on animal stable isotopes and fits a Bayesian model of the diet habits based on a Gaussian likelihood function with a Dirichlet prior mixture distribution for the mean.

The model also assumes that each target value (i.e. the stable isotope data for each individual) comes from a Gaussian distribution with an unknown mean and standard deviation. The structure of the mean is a weighted combination of the food sources' isotopic values. The standard deviation depends on the uncertainty in the fractionation corrections and the natural variability among target individuals within a defined group. We used the isotopic discrimination of $1.01 \pm 0.17 \%$ for $\mathrm{C}$ and $3.56 \pm 0.17 \%$ for $\mathrm{N}$ as the average of discrimination factors estimated for muscle analyses of different marine fish species provided in Caut et al. (2009).

\section{Trophic level}

To estimate the trophic levels (TL) of the different individuals we used the equation:

$\mathrm{TL}_{\text {consumer }}=\mathrm{TL}_{\text {basal }}+\left(\delta^{15} \mathrm{~N}_{\text {consumer }}-\delta^{15} \mathrm{~N}_{\text {prey }}\right) / \Delta \delta^{15} \mathrm{~N}$

$\mathrm{TL}_{\text {consumer }}$ refers to the mean TL of each individual fish. $\delta^{15} \mathrm{~N}_{\text {prey }}$ and $\delta^{15} \mathrm{~N}_{\text {consumer }}$ were, respectively, the isotopic values of microplankton and individual fish obtained in the present study (in each season). We applied a basal trophic level ( $\mathrm{TL}_{\text {basal }}$ ) of 1.5, assuming that the microplankton (mostly composed by phytoplankton) showed a trophic level between 1 of primary producers and 2 of micro- and mesozooplankton (Coll et al. 2006). The values of the isotopic discrimination factor for $\mathrm{N}\left(\Delta \delta^{15} \mathrm{~N}\right)$ were the same used for the isotopic mixing model (estimated from Caut et al. 2009).

\section{Selectivity index}

The output data of the SIAR model, together with the relative composition of the functional groups of plankton in the environment, were used to estimate the Ivlev diet selectivity index (Ivlev 1961, Krebs 1989) for each case analyzed. The value of the index was calculated with the equation:

$$
\left(r_{i}-p_{i}\right) /\left(r_{i}+p_{i}\right)
$$

where $r_{i}$ is the proportion of prey item $i$ calculated from the SIAR model and $p_{i}$ is the proportion of prey item $i$ available from the marine environment.

\section{Statistical analysis}

ANOVA tests were used to examine the differences in both $\delta^{13} \mathrm{C}$ and $\delta^{15} \mathrm{~N}$ values among species and ages in each season (summer, autumn and winter). Post hoc comparisons for observed means were performed with a Tukey test. The assumptions of ANOVA were checked with a Kolmogorov-Smirnov test for normality and a Levene test for homogeneity of variances. All analyses were performed with SPSS v.19 statistical software. A significance level of $p<0.05$ was used for all tests unless otherwise stated.

\section{RESULTS}

\section{Plankton composition}

The microplankton samples were composed primarily of phytoplankton (mainly diatoms; to a lesser extent, dinoflagellates, such as Ceratium spp. and Peridinium spp.; and tintinnids), together with high numbers of copepod nauplii during the summer and winter and small copepods, especially Oncaea spp., throughout the year and, during the winter, Paracalanus parvus. Mesozooplankton was dominated by copepods (mainly calanoids). The plankton community also included a relatively less important number of appendicularians during the autumn and winter (Fig. 2). Cladocerans occurred during summer but not during other seasons (Fig. 2).

\section{Isotopic differences}

Sardina pilchardus showed lower $\delta^{15} \mathrm{~N}$ values in summer and the highest $\delta^{15} \mathrm{~N}$ values in autumn, except for late-larvae (winter), which had significantly lower $\delta^{15} \mathrm{~N}$ values than in any other age group and season (Table 1, Fig. 3). Regarding S. pilchardus $\delta^{13} \mathrm{C}$ values (juveniles and adults), there were no significant differences $(p=0.25)$ between autumn and winter seasons (Table 2 ), while summer $\delta^{13} \mathrm{C}$ val- 

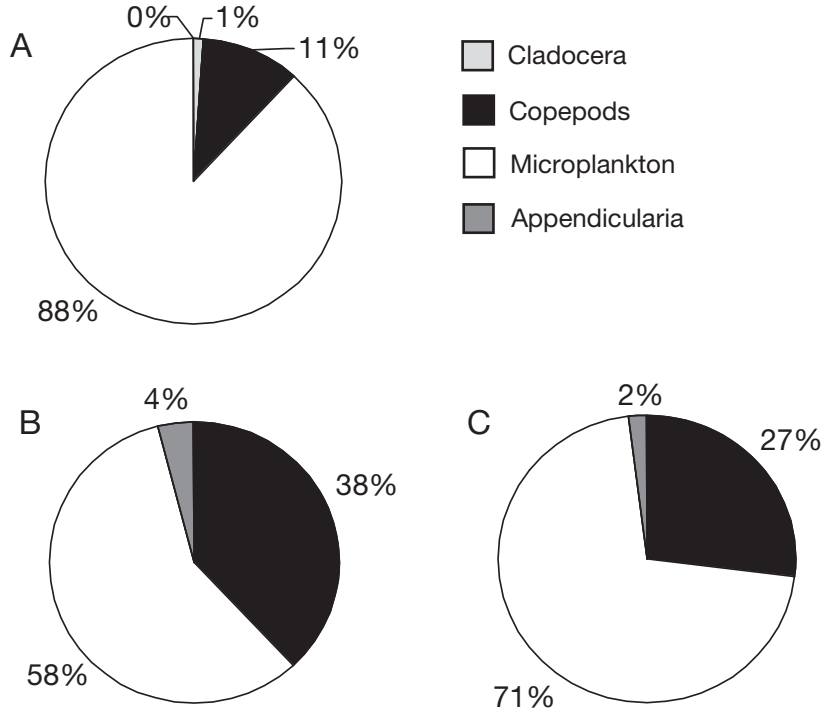

Fig. 2. Composition of plankton community in the Gulf of Lions during (A) summer, (B) autumn and (C) winter showing proportions of the 4 dietary functional groups defined in the present study differences during the summer for both juveniles and adults. E. encrasicolus latelarvae (summer) had higher $\delta^{13} \mathrm{C}$ values than adults.

The comparisons between the 2 species showed that, during the summer, the $\delta^{15} \mathrm{~N}$ values of Sardina pilchardus and Engraulis encrasicolus adults differed significantly. During the autumn, only differences between adults' $\delta^{15} \mathrm{~N}$ values were significant between species. During the winter, however, both the adults and juveniles exhibited significant species differences in $\delta^{15} \mathrm{~N}$ values. The $\delta^{13} \mathrm{C}$ values of the juveniles also differed between the species in winter and summer (Tables 1 \& 2, Fig. 3). A comparison of the late-larvae (E. encrasicolus in summer and $S$. pilchardus in winter) found statistically significant differences in the values of both $\delta^{13} \mathrm{C}$ and $\delta^{15} \mathrm{~N}$ (Table 2).

Concerning types of prey, appendicularians showed higher $\delta^{15} \mathrm{~N}$ values than other types in all seasons (Table 3, Fig. 3). Excluding summer, microplankton presented the lowest $\delta^{15} \mathrm{~N}$ values. The $\delta^{13} \mathrm{C}$ values are generally variable between seasons (Fig. 3). ues were statistically different from the other 2 seasons (Tables 1 \& 2, Fig. 3). $S$. pilchardus late-larvae (winter) also showed significantly lower values of $\delta^{13} \mathrm{C}$ compared to adults and juveniles (Table 2). S. pilchardus values of $\delta^{13} \mathrm{C}$ and $\delta^{15} \mathrm{~N}$ did not differ in autumn between adults and juveniles $\left(\mathrm{p}=0.870\right.$ for $\delta^{15} \mathrm{~N}, \mathrm{p}=$ 0.213 for $\delta^{13} C_{i}$ Table 1$)$. For both $S$. pilchardus age groups (juveniles and adults) analysed together, $\delta^{13} \mathrm{C}$ appeared to differ between the summer and other seasons, and $\delta^{15} \mathrm{~N}$ differed between winter and the other seasons (Table 1, Fig. 3).

Engraulis encrasicolus $\delta^{15} \mathrm{~N}$ isotopic values in both autumn and winter displayed marked differences between adults and juveniles (Table 1, Fig. 3). E. encrasicolus late-larvae (summer) had significantly higher values of $\delta^{15} \mathrm{~N}$ than juveniles (Table 1, Fig. 3). No differences in $\delta^{15} \mathrm{~N}$ values were observed among seasons for adult $E$. encrasicolus, whereas $\delta^{15} \mathrm{~N}$ values were statistically different for juveniles during autumn than in other seasons. When adults and juveniles were considered together, significant differences in $\delta^{15} \mathrm{~N}$ values were found among the 3 periods (Table 1, Fig. 3). E. encrasicolus $\delta^{13} \mathrm{C}$ values exhibited substantial
Table 1. Engraulis encrasicolus, Sardina pilchardus. Sample size, mean \pm $\mathrm{SD}$ of standard length (SL), stable isotope values $\left(\delta^{15} \mathrm{~N}\right.$ and $\left.\delta^{13} \mathrm{C}\right)$ and trophic level (TL) of different age groups of E. encrasicolus and $S$. pilchardus (adult, juvenile and late-larva) during summer, autumn and winter in the Gulf of Lions

\begin{tabular}{|lrrccc|}
\hline & $\mathrm{n}$ & $\mathrm{SL}(\mathrm{cm})$ & $\delta^{13} \mathrm{C}(\%)$ & $\delta^{15} \mathrm{~N}(\%)$ & $\mathrm{TL}$ \\
\hline $\begin{array}{l}\text { E. encrasicolus } \\
\text { Summer }\end{array}$ & & & & & \\
Adult & 15 & $11.57 \pm 0.44$ & $-19.56 \pm 0.16$ & $8.23 \pm 0.34$ & $2.42 \pm 0.09$ \\
Juvenile & 15 & $6.37 \pm 0.85$ & $-18.26 \pm 0.41$ & $7.78 \pm 0.41$ & $2.27 \pm 0.12$ \\
Late-larva & 15 & $2.15 \pm 0.16$ & $-18.38 \pm 0.11$ & $8.14 \pm 0.32$ & $2.39 \pm 0.09$ \\
Autumn & & & & & \\
Adult & 14 & $10.58 \pm 0.18$ & $-17.83 \pm 0.32$ & $8.16 \pm 0.48$ & $2.90 \pm 0.13$ \\
Juvenile & 15 & $8.11 \pm 0.49$ & $-17.67 \pm 0.29$ & $8.53 \pm 0.45$ & $3.05 \pm 0.12$ \\
Winter & & & & & \\
Adult & 7 & $8.80 \pm 0.23$ & $-17.42 \pm 0.22$ & $8.07 \pm 033$ & $2.63 \pm 0.09$ \\
Juvenile & 15 & $7.57 \pm 0.17$ & $-17.38 \pm 0.24$ & $7.54 \pm 0.53$ & $2.45 \pm 0.15$ \\
S. pilchardus & & & & & \\
Summer & & & & & \\
Adult & 17 & $13.62 \pm 0.43$ & $-19.32 \pm 1.16$ & $8.52 \pm 0.43$ & $2.53 \pm 0.12$ \\
Juvenile & 15 & $7.02 \pm 0.20$ & $-17.51 \pm 0.21$ & $7.97 \pm 0.29$ & $2.33 \pm 0.08$ \\
Autumn & & & & & \\
Adult & 15 & $12.91 \pm 0.87$ & $-17.68 \pm 0.71$ & $8.91 \pm 0.48$ & $3.22 \pm 0.13$ \\
Juvenile & 15 & $9.11 \pm 0.93$ & $-17.97 \pm 0.52$ & $8.95 \pm 0.84$ & $3.24 \pm 0.23$ \\
Winter & & & & & \\
Adult & 15 & $11.35 \pm 0.91$ & $-17.64 \pm 0.37$ & $8.69 \pm 0.41$ & $2.87 \pm 0.12$ \\
Juvenile & 14 & $9.74 \pm 0.52$ & $-17.77 \pm 0.41$ & $8.88 \pm 0.53$ & $2.95 \pm 0.14$ \\
Late-larva & 15 & $3.12 \pm 0.11$ & $-18.10 \pm 0.21$ & $6.74 \pm 0.42$ & $2.19 \pm 0.12$ \\
\hline
\end{tabular}




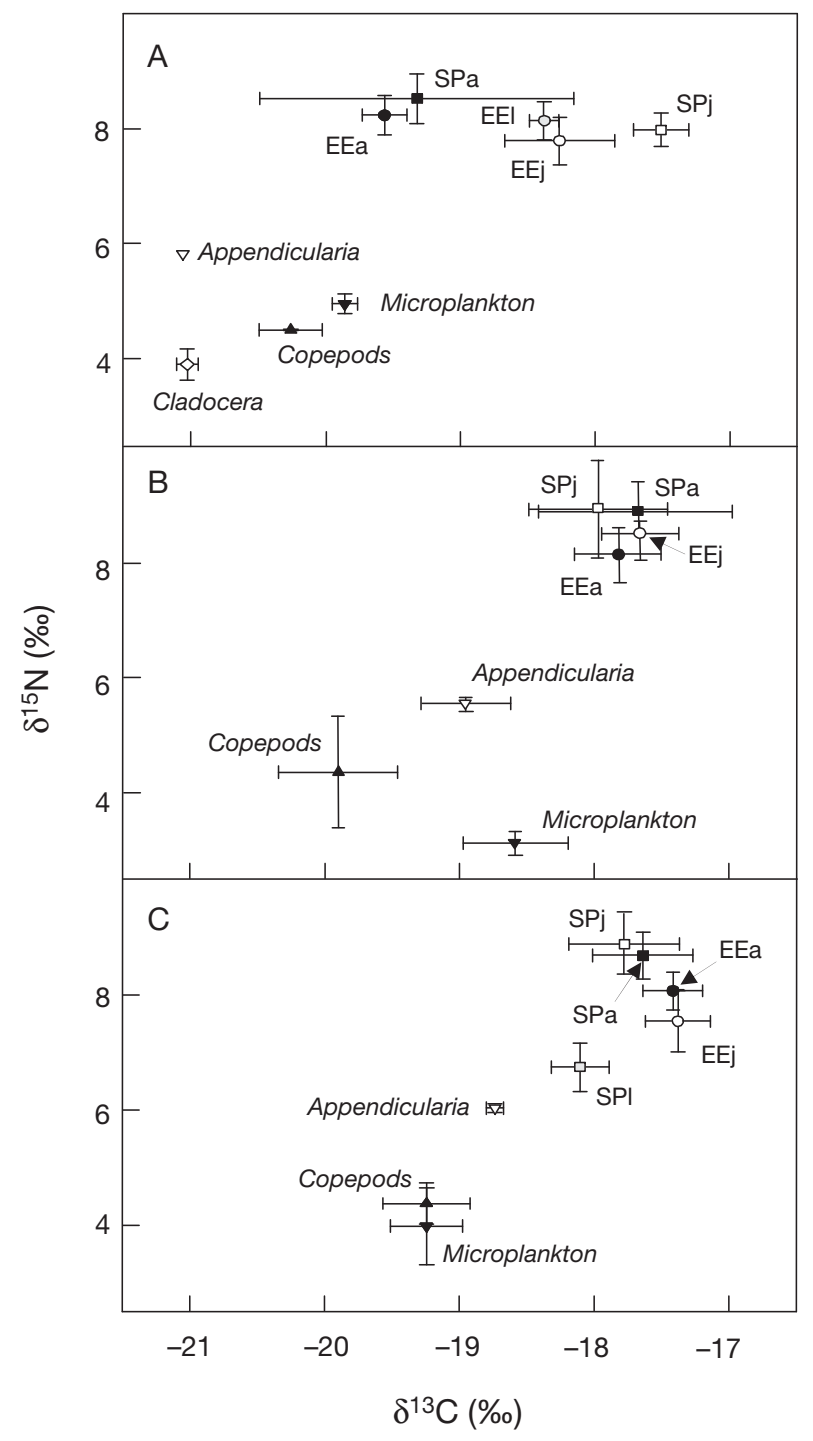

Fig. 3. Engraulis encrasicolus, Sardina pilchardus. $\delta^{15} \mathrm{~N}$ and $\delta^{13} \mathrm{C}$ values (mean $\pm \mathrm{SD}$ ) of $E$. encrasicolus late-larvae (EEl), juveniles (EEj) and adults (EEa), and $S$. pilchardus late-larvae (SPl), juveniles (SPj) and adults ( $\mathrm{SPa}$ ) during (A) summer, (B) autumn and (C) winter. Reference values for the main prey groups (see Fig. 2) in each season are also given

\section{Dietary differences}

The diets estimated with the SIAR model (isotopic values in Tables 1 \& 3) indicated that during the summer, Engraulis encrasicolus adults fed on cladocerans $(37.8 \%)$ and appendicularians $(24.7 \%)$, whereas juveniles fed primarily on cladocerans $(33.8 \%)$ and copepods $(35.5 \%)$. The juveniles also fed on microplankton $(27.1 \%)$. The late-larvae fed primarily on microplankton $(50.2 \%)$ and also on copepods
(35\%) (Fig. 4). During the summer, Sardina pilchardus adults had a heterogeneous diet, with appendicularians $(29.2 \%)$ as the main prey. The diet of $S$. pilchardus juveniles was based on cladocerans

Table 2. Summary of the ANOVA results for inter-seasonal (summer, autumn and winter) variation in stable isotopes over species and age of Engraulis encrasicolus and Sardina pilchardus in the Gulf of Lions. Abbreviations for age combinations in Tukey post hoc test summaries are-L: late-larvae; $\mathrm{J}$ : juvenile; A: adults; pairs of means differing significantly $(p=0.05)$ by Tukey test are linked with an ' $\mathrm{x}$ '

\begin{tabular}{|c|c|c|c|c|c|}
\hline & Effect & $F$ & df & $\mathrm{p}$ & Post hoc \\
\hline \multicolumn{6}{|c|}{ Summer } \\
\hline \multirow[t]{3}{*}{$\delta^{15} \mathrm{~N}$} & Species & 6.55 & 1,75 & $<0.001$ & \\
\hline & Age & 14.83 & 1,75 & $<0.001$ & AxL \\
\hline & Species $\times$ Age & 0.25 & 2,75 & 0.62 & \\
\hline \multirow[t]{3}{*}{$\delta^{13} \mathrm{C}$} & Species & 10.87 & 1,75 & 0.002 & \\
\hline & Age & 57.54 & 2,75 & $<0.001$ & $\mathrm{AxL}, \mathrm{JxL}, \mathrm{A}$ \\
\hline & Species $\times$ Age & 2.89 & 1,75 & 0.11 & \\
\hline \multicolumn{6}{|c|}{ Autumn } \\
\hline \multirow[t]{3}{*}{$\delta^{15} \mathrm{~N}$} & Species & 14.71 & 1,58 & $<0.001$ & \\
\hline & Age & 1.85 & 1,58 & 0.18 & \\
\hline & Species $\times$ Age & 1.19 & 1,58 & 0.28 & \\
\hline \multirow[t]{3}{*}{$\delta^{13} \mathrm{C}$} & Species & 0.38 & 1,58 & 0.54 & \\
\hline & Age & 0.27 & 1,58 & 0.61 & \\
\hline & Species $\times$ Age & 2.98 & 1,58 & 0.89 & \\
\hline \multicolumn{6}{|c|}{ Winter } \\
\hline \multirow[t]{3}{*}{$\delta^{15} \mathrm{~N}$} & Species & 51.58 & 1,65 & $<0.001$ & \\
\hline & Age & 96.81 & 2,65 & $<0.001$ & LxJ, A \\
\hline & Species $\times$ Age & 7.03 & 1,65 & 0.07 & \\
\hline \multirow[t]{3}{*}{$\delta^{13} \mathrm{C}$} & Species & 11.45 & 1,65 & $<0.001$ & \\
\hline & Age & 8.29 & 2,65 & $<0.001$ & LxJ, A \\
\hline & Species $\times$ Age & 0.93 & 1,65 & 0.34 & \\
\hline
\end{tabular}

Table 3. Sample size (n), mean \pm SD of stable isotope values $\left(\delta^{15} \mathrm{~N}\right.$ and $\delta^{13} \mathrm{C}$ ) of prey groups during summer, autumn and winter in the Gulf of Lions

\begin{tabular}{|lccc|}
\hline & $\mathrm{n}$ & $\delta^{13} \mathrm{C}(\%)$ & $\delta^{15} \mathrm{~N}(\%)$ \\
\hline Summer & & & \\
Cladocera & 3 & $-21.03 \pm 0.08$ & $3.90 \pm 0.27$ \\
Copepods & 3 & $-20.26 \pm 0.23$ & $4.50 \pm 0.01$ \\
Microplankton & 3 & $-19.85 \pm 0.09$ & $4.95 \pm 0.17$ \\
Appendicularia & 1 & -21.06 & 5.82 \\
Autumn & & & \\
Copepods & 3 & $-19.90 \pm 0.44$ & $4.38 \pm 0.97$ \\
Microplankton & 4 & $-18.59 \pm 0.38$ & $3.13 \pm 0.20$ \\
Appendicularia & 2 & $-18.96 \pm 0.33$ & $5.55 \pm 0.12$ \\
Winter & & & \\
Copepods & 3 & $-19.24 \pm 0.32$ & $4.37 \pm 0.36$ \\
Microplankton & 5 & $-19.24 \pm 0.27$ & $3.98 \pm 0.67$ \\
Appendicularia & 3 & $-18.74 \pm 0.06$ & $6.03 \pm 0.08$ \\
\hline
\end{tabular}




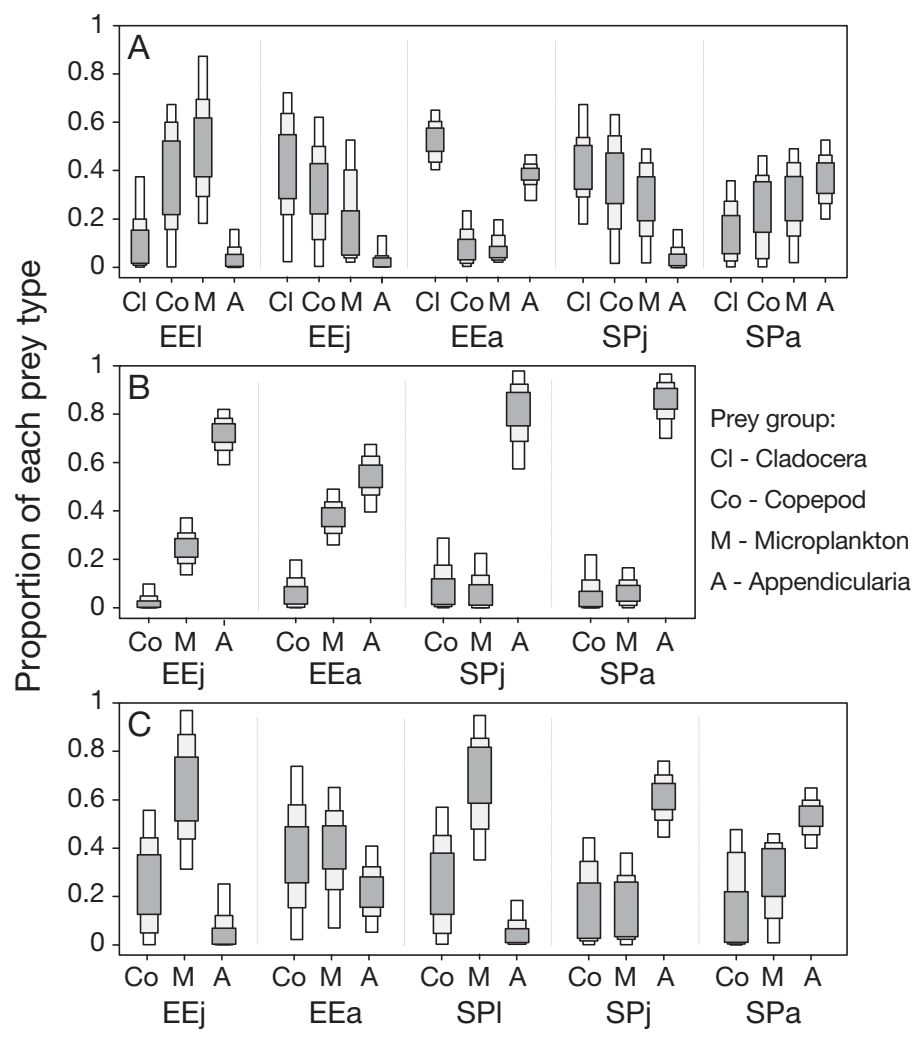

Fig. 4. Engraulis encrasicolus, Sardina pilchardus. Results of stable isotope analysis in R $(95,75$ and $50 \%$ credibility intervals) showing estimated prey contributions to the diet of E. encrasicolus late-larvae (EEl), juveniles (EEj) and adults (EEa), and $S$. pilchardus late-larvae (SPl), juveniles ( $\mathrm{SPj}$ ) and adults $(\mathrm{SPa})$ from the Gulf of Lions (northwestern Mediterranean) during (A) summer, (B) autumn and $(\mathrm{C})$ winter

(36.8\%), copepods (33.5\%) and microplankton $(25.1 \%)$ (Fig. 4).

During the autumn, the diets of adults were similar to the diets of juveniles for both Sardina pilchardus and Engraulis encrasicolus. The main prey types for $S$. pilchardus were appendicularians (88\% in adults and $82.8 \%$ in juveniles). Appendicularians were also the primary prey item for $E$. encrasicolus $(59.4 \%$ in adults and $75.4 \%$ in juveniles) (Fig. 4).

Sardina pilchardus adults and juveniles in winter also showed a diet based on appendicularians (49\% in adults and $58.1 \%$ in juveniles), but the primary prey item of late-larvae was microplankton (56.1\%). In the same season Engraulis encrasicolus juveniles fed primarily on microplankton (69\%), whereas adult $E$. encrasicolus fed primarily on copepods and appendicularians in similar amounts (40.7 and $40.8 \%$, respectively) (Fig. 4).

\section{Prey selectivity}

Ivlev's selectivity index showed that during the summer, both cladocerans and appendicularians were the most heavily selected prey (Fig. 5). Positive selection was also exhibited for copepods, while microplankton was negatively selected in all cases (Fig. 5). During autumn, appendicularians were generally preferred. An apparent neutral selection was shown for copepods, and negative selection was shown for microplankton (Fig. 5). During the winter, copepods, followed by appendicularians, were highly selected in nearly all cases. The only exception was Sardina pilchardus late-larvae, which did not select appendicularians. Microplankton was not positively selected in any case (Fig. 5).

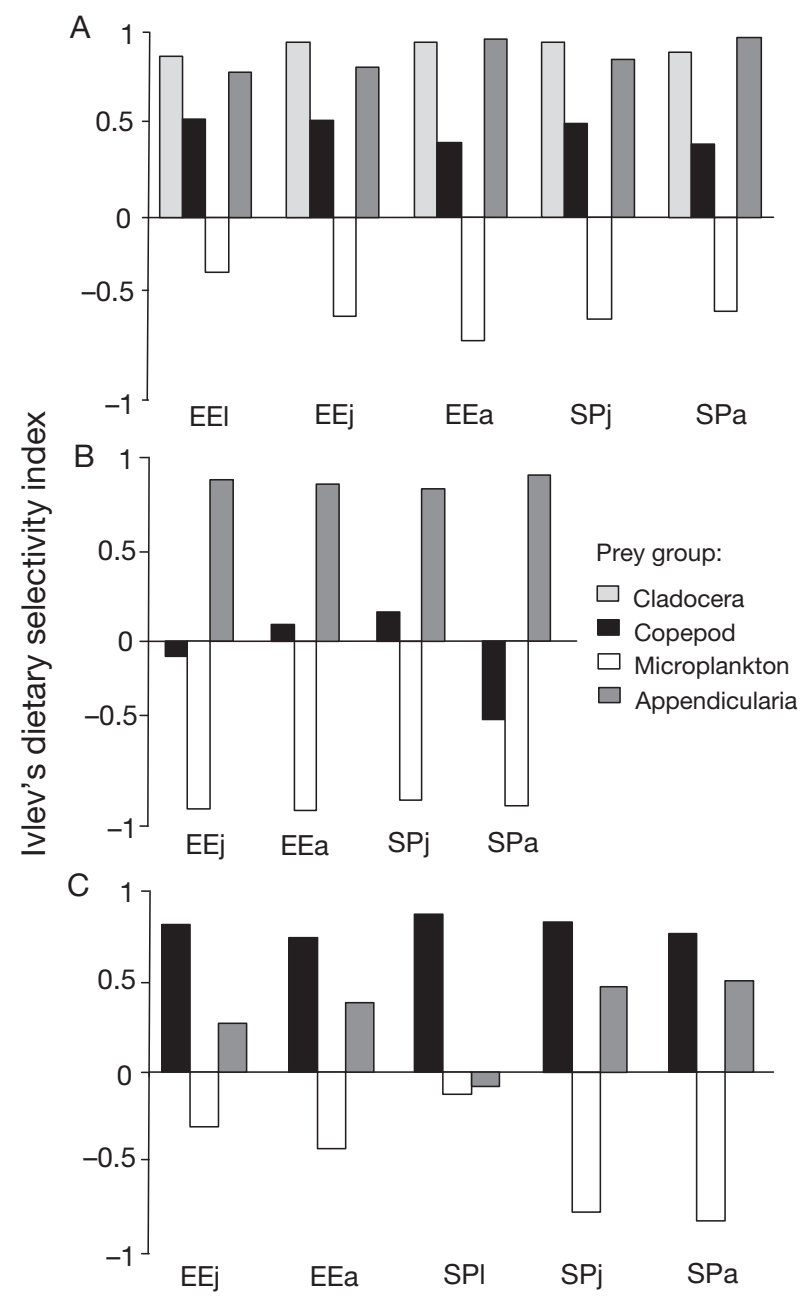

Fig. 5. Engraulis encrasicolus, Sardina pilchardus. Ivlev's dietary selectivity index for E. encrasicolus late-larvae (EEl), juveniles (EEj) and adults (EEa), and $S$. pilchardus latelarvae (SPl), juveniles (SPj) and adults (SPa) during (A) summer, (B) autumn and (C) winter 


\section{DISCUSSION}

Our study determined the trophic dynamics of anchovy Engraulis encrasicolus and sardine Sardina pilchardus during different seasons and at different life stages. The results of the study emphasised the feeding plasticity of these species in the Gulf of Lions, as already observed in the Adriatic Sea (Borme et al. 2009). The results showed that the late-larvae of both species feed more abundantly on microplankton than on any other prey and that a remarkable difference in the diet occurred after metamorphosis. If cladocerans were available (i.e. during the summer), they were usually the preferred prey. The high selectivity for appendicularians in autumn seemed to explain the high trophic levels found for this season because appendicularians are the prey group with the highest $\delta^{15} \mathrm{~N}$ values. These high $\delta^{15} \mathrm{~N}$ values of appendicularians could be due to the retention of zooplankton organisms of high $\delta^{15} \mathrm{~N}$ values, such as carnivorous copepods or even small larvae, on their houses (Deibel \& Lee 1992); this is in accordance with the data of Hobson et al. (2002), who obtained a higher value of stable-nitrogen isotope and a higher trophic level in appendicularians than in mixed zooplankton samples.

The difference in trophic levels between Engraulis encrasicolus and Sardina pilchardus late-larvae resulted from their distinct feeding behaviour. E. encrasicolus late-larvae, which showed values of $\delta^{15} \mathrm{~N}$ similar to those in the other stages, generally fed on copepods and microplankton, a diet similar to that of $S$. pilchardus late-larvae. However, despite the high proportion of these types of prey in the sea during summer, E. encrasicolus late-larvae have been found to feed preferentially on appendicularians and cladocerans if these food items are available. Morote et al. (2010) found that E. encrasicolus larvae $<15 \mathrm{~mm}$ standard length (SL) fed primarily on copepods and cladocerans (see also Tudela et al. 2002), whereas $S$. pilchardus ate a relatively high number of protists along with copepod nauplii. Other studies of $S$. pilchardus larvae $>13 \mathrm{~mm}$ SL reported a diet based on phytoplankton (Rasoanarivo et al. 1991). Given the mean SL of the larvae examined in the current study, it is probable that they did not retain the isotopic signal from parental feeding activity (Pepin \& Dower 2007). In view of these considerations and the results cited, it seems reasonable to suppose that $S$. pilchardus late-larvae, whose diet is more herbivorous, would exhibit a lower trophic level than that of $E$. encrasicolus late-larvae. This difference is even clearer from the selectivity indices, which indicate that E. encrasicolus late-larvae tend to feed on prey with higher $\delta^{15} \mathrm{~N}$ values rather than on the microplankton that represent a primary constituent of the diet of $S$. pilchardus late-larvae.

The observed differences between ages during the winter and summer for Engraulis encrasicolus and Sardina pilchardus reflected a change in the diet across the ontogenetic development of the fishes. We did not find differences during autumn, because no late-larvae of any species were collected during that period. These findings suggested the hypothesis that the diet shift occurred primarily at the time of metamorphosis (Lindsay et al. 1998), whereas juveniles and adults maintained similar diets. However, E. encrasicolus during summer exhibited clear differences between juveniles and the other 2 stages. Lindsay et al. (1998) also found a drastic change in $\delta^{15} \mathrm{~N}$ in Japanese anchovy E. japonicus as individuals grew from 15 to $30 \mathrm{~mm}$ SL and another change between 30 and $70 \mathrm{~mm}$ SL. These size ranges are almost coincident with the sizes of the juveniles in our study ( $6.37 \pm 0.85 \mathrm{~cm}$ of SL). Therefore, dietary changes may also occur after metamorphosis.

The most frequently cited explanation for the ontogenetic dietary shift refers to the development of the feeding apparatus of the fishes (June \& Carlson 1971, King \& Macleod 1976, MacNeill \& Brandt 1990, Gerking 1994). According to these authors, larvae become able to filter-feed when the development of their gill rakers is complete. Thus, differences in the diet are related to the minimum prey sizes that are efficiently retained by the feeding apparatus.

In contrast, Tanaka et al. (2006) analysed the stomach contents and gill-raker morphology of 3 species of planktivorous pelagic fishes. These authors found that the differences in the diets of these species were explained by differences in feeding behaviour (filterfeeding vs. particulate feeding) rather than by differences in morphology. This conclusion supports our results for juveniles and adults of E. encrasicolus during summer. These fish, caught at different locations and different times, are considered to have a fully developed filtering apparatus. Consequently, the differences in the diet indicated here by stable isotopes could depend on shifts in feeding habits mediated by food density. For example, the fish could shift between filter-feeding and particulate feeding, depending on the concentrations of different prey items (Bulgakova 1996).

Previous studies based on stomach contents analysis argued that Engraulis encrasicolus in the Gulf of Lion is mainly zooplanktivorous (Tudela \& Palomera 1997, Plounevez \& Champalbert 2000, Morote et al. 
2010, Costalago et al. 2011), whereas Sardina pilchardus also feeds significantly on microheterotrophs (Rasoanarivo et al. 1991, Morote et al. 2010). These observations, together with our results, led us to hypothesise that both E. encrasicolus and $S$. pilchardus are omnivorous all through their life cycles. However, our results demonstrated a slightly higher trophic level for $S$. pilchardus in all seasons and stages, except late-larvae, a similar pattern to that described for the Atlantic coast of the Iberian Peninsula (Bode et al. 2007). This discrepancy was explained by van der Lingen (1998) and Bode et al. (2006), who demonstrated that sardines primarily obtain protein nitrogen from zooplankton rather than from phytoplankton. This argument is also supported by the observation that herbivores generally have higher $\delta^{15} \mathrm{~N}$ variability (Mill et al. 2007). Moreover, the differences between the present study and those by Coll et al. (2006) and Navarro et al. (2011), both focused on the Catalan Sea, could be considered a consequence of the diet data used by those authors. In particular, they based their results on anchovy diet data reported by Tudela \& Palomera (1997) and on sardine diet data from the eastern Mediterranean (Demirhindi 1961), resulting in a higher trophic level in E. encrasicolus than in sardine (3.05 and 2.97, respectively). Alternatively, some differences in the diets of $E$. encrasicolus and $S$. pilchardus between areas may also have influenced these results.

A comparison of the trophic levels found in our study with values from upwelling areas shows that adults of both anchovy and sardine in the Gulf of Lions normally exhibited trophic levels similar to the trophic levels found for homologous species in regions with upwelling. Bode et al. (2007) found trophic levels of 3.5 for Sardina pilchardus and of 3.4 for Engraulis encrasicolus for the northern Iberian Atlantic coast. Miller et al. (2010) found trophic levels of 2.9 for S. sagax and of 3.1 for E. mordax for the California Current. Moreover, the trophic level of 2.9 derived for $S$. sagax in the southern Benguela Current is lower than the value for $S$. pilchardus in the Gulf of Lions (van der Lingen \& Miller 2011). In this context, Miller et al. (2011) showed that fish from less productive areas exhibited relatively higher trophic levels than those from more productive areas. Therefore, the food web of areas with relatively low average primary production, like the Gulf of Lions, is more linear than the food web in zones with upwelling (e.g. the Galician coast, where the trophic structure is more intricate and ramified) (Agostini \& Bakun 2002). A more linear food web implies that individuals, in this case small pelagic fish in the Mediterranean sea, are more dependent on the adjacent lower trophic level than those small pelagic fish from more highly productive areas (Miller et al. 2011), a pattern that could be interpreted as a bottom-up ecosystem structure in the Mediterranean. However, in view of the high biomass of the mid-trophic level small pelagic fish in the northwestern Mediterranean, this structure is actually closer to a 'wasp-waist' system, as found in the Adriatic Sea (Coll et al. 2007).

The trophic dynamics of zooplankton and small pelagic fish occupy the most significant position within marine pelagic food webs (Shannon et al. 2009). In the Gulf of Lions, a substantial amount of seasonal variability affecting the lower trophic levels has been widely reported (Molinero et al. 2005). These temporal fluctuations reflect an important feature of the area - the effect of the Rhone River. The Rhone is the primary source of the runoff entering the Mediterranean. The mean annual flow of the river is $1700 \mathrm{~m}^{3} \mathrm{~s}^{-1}$, and its catchment area is 98000 $\mathrm{km}^{2}$ (Darnaude et al. 2004). In fact, correlations between river discharge and marine pelagic fish abundance in the northwestern Mediterranean have been extensively studied (García \& Palomera 1996, Lloret et al. 2001, 2004) and are generally explained by the enhancement of planktonic production produced by the input of nutrients from rivers. We found significant differences in the $\delta^{13} \mathrm{C}$ signatures of fishes among seasons in all cases. These results demonstrate the importance of seasonal variability for the structure of the food web.

Lindsay et al. (1998) also found that, in central Japan, rivers may supply the coastal trophic web with different $\delta^{15} \mathrm{~N}$ signatures depending on the season. In agreement with this result, our study showed that this heavy nitrogen isotope was generally more abundant in both food sources and fish samples during autumn. The difference may reflect the higher amount of rainfall during autumn in this region. Moreover, Odum (1985) suggested that the augmented contributions of flows to detritus could serve as a marker of disruption in energy transport from lower to higher trophic levels, conferring higher signature to $\delta^{15} \mathrm{~N}$ than expected with a less direct transmission to predators. With this in mind, it can be argued that nutrients derived from the Rhone River in autumn tend to have heavier N. Correspondingly, we showed that $\delta^{15} \mathrm{~N}$ values in summer were generally lower for the 2 fish species than in the other 2 studied seasons, probably because summer is the driest season and the river discharges are lower. 
In conclusion, the present study shows that adults of Engraulis encrasicolus and Sardina pilchardus generally prey over larger plankton than juveniles and late-larvae. We also illustrate the importance of appendicularians in the diet of both species, especially when cladocerans are not available, and prove that stable isotope analysis is an essential tool for complement dietary studies based on direct observations of stomach contents, because appendicularians are likely easily digested (Capitanio et al. 2005) and could have been underestimated in some cases (Capitanio et al. 1997, D. Costalago unpubl. data). Moreover, based on our output data from the SIAR model and the data we gathered from the plankton samples, we also showed an innovative manner of calculating dietary selectivity through Ivlev's selectivity index. To our knowledge, this approach has never previously been attempted, and we believe that, with limitations and future improvements, it can be useful for drawing a more comprehensive and accurate picture of trophic dynamics.

Assessing the isotopic values of different types of prey in different seasons is therefore essential in understanding whether isotopic seasonal variations of pelagic fish are caused by changes in diet or by variations of basal isotopic levels due to environmental oscillations. Anthropogenic alterations in the ecosystem, such as overfishing, eutrophication, or climate change often entail alterations in the trophic structure of the communities; therefore, the abovediscussed findings may be useful in future management scenarios that would take into account an ecosystem approach to fisheries in the northwestern Mediterranean.

Acknowledgements. The authors gratefully acknowledge the collaboration of the IFREMER-Sète scientific staff, B. Liorzou, J. L. Bigot, D. Ross and L. Butay, and of the captain and crew of the RV 'L'Europe' for their help during the cruises. We also thank B. Molí for collaboration during the autumn cruise. We are very grateful to J. González-Solís (UB) for his help with the isotopic analyses. D.C. was funded by a PhD contract within the European project SARDONE (FP6-44294). J.N. was supported by a postdoctoral contract from the Juan de la Cierva programme (MICINN-JDC, Spanish Ministry of Science and Innovation).

\section{LITERATURE CITED}

Agostini VN, Bakun A (2002) 'Ocean triads' in the Mediterranean Sea: physical mechanisms potentially structuring reproductive habitat suitability (with example application to European anchovy, Engraulis encrasicolus). Fish Oceanogr 11:129-142

Bakun A (1996) Patterns in the ocean. Ocean processes and marine population dynamics. California Sea Grant Col- lege System, Centro de Investigaciones Biológicas del Noroeste, La Paz, México

Barangé M, Coetzee J, Takasuka A, Hill K and others (2009) Habitat expansion and contraction in anchovy and sardine populations. Prog Oceanogr 83:251-260

Barausse A, Duci A, Mazzoldi C, Artioli Y, Palmeri L (2009) Trophic network model of the northern Adriatic Sea: analysis of an exploited eutrophic ecosystem. Estuar Coast Shelf Sci 83:577-590

Bode A, Carrera P, Porteiro C (2006) Stable nitrogen isotopes reveal weak dependence of trophic position of planktivorous fish on individual size: a consequence of omnivorism and mobility. In: Povinec P, Sanchez-Cabeza JA (eds) International conference on isotopes and environmental studies, Vol 8. Elsevier, Amsterdam, p 281-293

Bode A, Alvarez-Ossorio MT, Cunha ME, Garrido S and others (2007) Stable nitrogen isotope studies of the pelagic food web on the Atlantic shelf of the Iberian Peninsula. Prog Oceanogr 74:115-131

Borme D, Tirelli V, Brandt S, Fonda S, Arneri E (2009) Diet of Engraulis encrasicolus in the northern Adriatic Sea (Mediterranean): ontogenetic changes and feeding selectivity. Mar Ecol Prog Ser 392:193-209

> Buchheister A, Latour RJ (2010) Turnover and fractionation of carbon and nitrogen stable isotopes in tissues of a migratory coastal predator, summer flounder (Paralichthys dentatus). Can J Fish Aquat Sci 67:445-461

Bulgakova Y (1996) Feeding in the Black Sea anchovy: diet composition, feeding behaviour, feeding periodicity and daily rations. Sci Mar 60:283-284

Calbet A, Garrido S, Saiz E, Alcaraz M, Duarte CM (2001) Annual zooplankton succession in coastal NW Mediterranean waters: the importance of the smaller size fractions. J Plankton Res 23:319-331

Capitanio BF, Pajaro M, Esnal GB (1997) Appendicularians (Chardata, Tunicata) in the diet of anchovy (Engraulis anchoita) in the Argentine Sea. Sci Mar 61:9-15

Capitanio BF, Pajaro M, Esnal GB (2005) Appendicularians: an important food supply for the Argentine anchovy Engraulis anchoita in coastal waters. J Appl Ichthyol 21: 414-419

> Catalán I, Folkvord A, Palomera I, Quílez-Badía G, Kallianoti F, Tselepides A, Kallianotis A (2010) Growth and feeding patterns of European anchovy (Engraulis encrasicolus) early life stages in the Aegean Sea (NE Mediterranean). Estuar Coast Shelf Sci 86:299-312

> Caut S, Angulo E, Courchamp F (2009) Variation in discrimination factors $\left(\Delta^{15} \mathrm{~N}\right.$ and $\left.\Delta^{13} \mathrm{C}\right)$ : the effect of diet isotopic values and applications for diet reconstruction. J Appl Ecol 46:443-453

Coll M, Libralato S (2012) Contributions of food web modelling to the ecosystem approach to marine resource management in the Mediterranean Sea. Fish Fish 13:60-68

> Coll M, Palomera I, Tudela S, Sarda F (2006) Trophic flows, ecosystem structure and fishing impacts in the South Catalan Sea, northwestern Mediterranean. J Mar Syst 59:63-96

Coll M, Santojanni A, Palomera I, Tudela S, Arneri E (2007) An ecological model of the northern and central Adriatic Sea: analysis of ecosystem structure and fishing impacts. J Mar Syst 67:119-154

> Coll M, Palomera I, Tudela S, Dowd M (2008) Food-web dynamics in the South Catalan Sea ecosystem (NW Mediterranean) for 1978-2003. Ecol Modell 217:95-116 
Conway DVP, Coombs SH, Smith C (1998) Feeding of anchovy Engraulis encrasicolus larvae in the northwestern Adriatic Sea in response to changing hydrobiological conditions. Mar Ecol Prog Ser 175:35-49

> Costalago D, Tecchio S, Palomera I, Alvarez-Calleja I, Ospina-Alvarez A, Raicevich S (2011) Ecological understanding for fishery management: condition and growth of anchovy late larvae during different seasons in the northwestern Mediterranean. Estuar Coast Shelf Sci 93: 350-358

Cury P, Bakun A, Crawford RJM, Jarre-Teichmann A, Quinones R, Shannon LJ, Verheye HM (2000) Small pelagics in upwelling systems: patterns of interaction and structural changes in 'wasp-waist' ecosystems. ICES J Mar Sci 57:603-618

> Darnaude AM, Salen-Picard C, Polunin NVC, HarmelinVivien ML (2004) Trophodynamic linkage between river runoff and coastal fishery yield elucidated by stable isotope data in the Gulf of Lions (NW Mediterranean). Oecologia 138:325-332

Daskalov G (2002) Overfishing drives a trophic cascade in the Black Sea. Mar Ecol Prog Ser 225:53-63

$>$ Deibel D, Lee SH (1992) Retention efficiency of sub-micrometer particles by the pharyngeal filter of the pelagic tunicate Oikopleura vanhoeffeni. Mar Ecol Prog Ser 81: 25-30

Demirhindi U (1961) Nutrition of the sardine (Sardina pilchardus Walb.). Proceedings and Technical Papers of the General Fisheries Council for the Mediterranean 6: 253-259

Flaherty E, Ben-David M (2010) Overlap and partitioning of the ecological and isotopic niches. Oikos 119:1409-1416

García A, Palomera I (1996) Anchovy early life history and its relation to its surrounding environment in the western Mediterranean basin. Sci Mar 2:155-166

Gerking S (1994) Feeding ecology of fish. Academic Press, San Diego, CA

> Govoni JJ (2005) Fisheries oceanography and the ecology of the early life histories of fishes: a perspective over fifty years. Sci Mar 69:125-137

> Hobson KA, Fisk A, Karnovsky N, Holst M, Gagnon JM, Fortier $M$ (2002) A stable isotope $\left(\delta^{13} \mathrm{C}, \delta^{15} \mathrm{~N}\right)$ model for the North Water food web: implications for evaluating trophodynamics and the flow of energy and contaminants. Deep-Sea Res II 49:5131-5150

Hunter M, Price P (1992) Playing chutes and ladders: heterogeneity and the relative roles of bottom-up and top-down forces in natural communities. Ecology 73:724-732

Ivlev VS (1961) Experimental ecology of the feeding of fishes. Yale University Press, New Haven, CT

June FC, Carlson FT (1971) Food of young Atlantic menhanden, Brevoortia tyrannus, in relation to metamorphosis. Fish Bull 68:493-512

Klyashtorin LB (1998) Long-term climate change and main commercial fish production in the Atlantic and Pacific. Fish Res 37:115-125

Krebs CJ (1989) Ecological methodology. Harper Collins Publishers, New York, NY

- Libralato S, Christensen V, Pauly D (2006) A method for identifying keystone species in food web models. Ecol Modell 195:153-171

Lin HJ, Kao WY, Wang YT (2007) Analyses of stomach contents and stable isotopes reveal food resources of estuarine detritivorous fish in tropical/subtropical Taiwan. Estuar Coast Shelf Sci 73:527-537
Lindsay DJ, Minagawa M, Mitani I, Kawaguchi K (1998) Trophic shift in the Japanese anchovy Engraulis japonicus in its early life history stages as detected by stable isotope ratios in Sagami Bay, central Japan. Fish Sci 64:403-410

- Lloret J, Lleonart J, Sole I, Fromentin JM (2001) Fluctuations of landings and environmental conditions in the northwestern Mediterranean Sea. Fish Oceanogr 10:33-50

- Lloret J, Palomera I, Salat J, Sole I (2004) Impact of freshwater input and wind on landings of anchovy (Engraulis encrasicolus) and sardine (Sardina pilchardus) in shelf waters surrounding the Ebre (Ebro) River delta (northwestern Mediterranean). Fish Oceanogr 13:102-110

> Logan JM, Jardine TD, Miller TJ, Bunn SE, Cunjak RA, Lutcavage ME (2008) Lipid corrections in carbon and nitrogen stable isotope analyses: comparison of chemical extraction and modelling methods. J Anim Ecol 77: 838-846

> MacNeill D, Brandt S (1990) Ontogenetic shifts in gill-raker morphology and predicted prey capture efficiency of the alewife, Alosa pseudoharengus. Copeia 1990:164-171

Mill AC, Pinnegar JK, Polunin NVC (2007) Explaining isotope trophic-step fractionation: why herbivorous fish are different. Funct Ecol 21:1137-1145

Miller TW, Brodeur R, Rau G, Omori K (2010) Prey dominance shapes trophic structure of the northern California Current pelagic food web: evidence from stable isotopes and diet analysis. Mar Ecol Prog Ser 420:15-26

Miller TW, van der Lingen C, Brodeur R, Hamaoka H, Isobe $\mathrm{T}$ (2011) Understanding what drives food web structure in marine pelagic ecosystems. In: Omori $\mathrm{K}$, Guo $\mathrm{X}$, Yoshie N, Fujii N, Handoh IC, Isobe A, Tanabe S (eds) Interdisciplinary studies on environmental chemistrymarine environmental modeling and analysis. TERRAPUB, Tokyo, p 125-131

> Molinero JC, Ibanez F, Nival P (2005) North Atlantic climate and northwestern Mediterranean plankton variability. Limnol Oceanogr 50:1213-1220

Morello B, Arneri E (2009) Anchovy and sardine in the Adriatic Sea-an ecological review. Oceanogr Mar Biol Annu Rev 47:209-253

Morote E, Olivar MP, Villate F, Uriarte I (2010) A comparison of anchovy (Engraulis encrasicolus) and sardine (Sardina pilchardus) larvae feeding in the Northwest Mediterranean: influence of prey availability and ontogeny. ICES J Mar Sci 67:897-908

Motoda S (1959) Devices of simple plankton apparatus. Mem Fac Fish Hokkaido Univ 7:73-94

- Navarro J, Louzao M, Arcos JM, Delgado A and others (2009) Seasonal changes in the diet of a critically endangered seabird and the importance of trawling discards. Mar Biol 156:2571-2578

Navarro J, Coll M, Louzao M, Palomera I, Delgado A, Forero MG (2011) Comparison of ecosystem modelling and isotopic approach as ecological tools to investigate food web in the NW Mediterranean Sea. J Exp Mar Biol Ecol 401:97-104

Odum EP (1985) Trends expected in stressed ecosystems. Bioscience 35:419-422

Pace ML, Cole JJ, Carpenter SR, Kitchell JF (1999) Trophic cascades revealed in diverse ecosystems. Trends Ecol Evol 14:483-488

Palomera I, Olivar MP, Salat J, Sabates A, Coll M, Garcia A, Morales-Nin B (2007) Small pelagic fish in the NW Mediterranean Sea: an ecological review. Prog Oceanogr 74:377-396 
Parnell AC, Inger R, Bearhop S, Jackson AL (2010) Source partitioning using stable isotopes: coping with too much variation. PLoS ONE 5:e9672

Pepin P, Dower JF (2007) Variability in the trophic position of larval fish in a coastal pelagic ecosystem based on stable isotope analysis. J Plankton Res 29:727-737

Peterson BJ (1999) Stable isotopes as tracers of organic matter input and transfer in benthic food webs: a review. Acta Oecol 20:479-487

Phillips DL, Gregg JW (2001) Uncertainty in source partitioning using stable isotopes. Oecologia 127:171-179

Pinnegar JK, Polunin NVC (2000) Contributions of stableisotope data to elucidating food webs of Mediterranean rocky littoral fishes. Oecologia 122:399-409

$>$ Plounevez S, Champalbert G (2000) Diet, feeding behaviour and trophic activity of the anchovy (Engraulis encrasicolus L.) in the Gulf of Lions (Mediterranean Sea). Oceanol Acta 23:175-192

Polunin NV, Pinnegar J (2008) Trophic ecology and the structure of marine food webs. In: Hart PJ, Reynolds JD (eds) Handbook of fish biology and fisheries, Vol 1. Fish biology. Blackwell Publishing, Oxford

> Post DM (2002) Using stable isotopes to estimate trophic position: models, methods, and assumptions. Ecology 83: 703-718

R Development Core Team (2009) R: a language and environment for statistical computing. R Foundation for Statistical Computing, Vienna. www.R-project.org

Rasoanarivo R, Folack J, Champalbert G, Becker B (1991) Relations entre les communautés phytoplanctoniques et l'alimentation de Sardina pilchardus Walb. dans de golfe de Fos (Méditerrané occidentale): influence de la lumière sur l'activité alimentaire des larves. J Exp Mar Biol Ecol 151:83-92

Rice J (1995) Food web theory, marine food webs and what climate changes may do to northern marine fish populations. In.: Beamish RJ (ed) Climate change and northern fish populations. Can Spec Publ Fish Aquat Sci 121: 561-568

Rodríguez-Sanchez R, Lluch-Belda D, Villalobos H, OrtegaGarcia S (2002) Dynamic geography of small pelagic fish populations in the California Current System on the regime time scale (1931-1997). Can J Fish Aquat Sci 59: 1980-1988

Ruiz J, Garcia-Isarch E, Huertas IE, Prieto L and others (2006) Meteorological and oceanographic factors influencing Engraulis encrasicolus early life stages and catches in the Gulf of Cadiz. Deep-Sea Res II 53: 1363-1376

Salat J (1996) Review of hydrographic environmental factors that may influence anchovy habitats in northwestern Mediterranean. Sci Mar 60:21-32

Shannon L, Cury P, Jarre A (2000) Modelling effects of fish-

Editorial responsibility: Yves Cherel,

Villiers-en-Bois, France ing in the southern Benguela ecosystem. ICES J Mar Sci 57:720-722

Shannon L, Coll M, Neira S, Cury P, Roux JP (2009) Impacts of fishing and climate change explored using trophic models. In: Checkley DM, Roy C, Alheit J, Oozeki Y (eds) Climate change and small pelagic fish. Cambridge University Press, Cambridge, p 158-190

Sweeting CJ, Jennings S, Polunin NVC (2005) Variance in isotopic signatures as a descriptor of tissue turnover and degree of omnivory. Funct Ecol 19:777-784

Tanaka H, Aoki I, Ohshimo S (2006) Feeding habits and gill raker morphology of three planktivorous pelagic fish species off the coast of northern and western Kyushu in summer. J Fish Biol 68:1041-1061

Tripp-Valdez A, Arreguín-Sánchez F (2009) The use of stable isotopes and stomach contents to identify dietary components of the spotted rose snapper, Lutjanus guttatus (Steindachner, 1869), off the eastern coast of the southern Gulf of California. J Fish Aquat Sci 4:274-284

Tsagarakis K, Coll M, Giannoulaki M, Somarakis S, Machias A, Papaconstantinou C (2010) Food-web traits of the North Aegean Sea ecosystem (eastern Mediterranean) and comparison with other Mediterranean ecosystems. Estuar Coast Shelf Sci 88:233-248

> Tudela S, Palomera I (1997) Trophic ecology of the European anchovy Engraulis encrasicolus in the Catalan Sea (northwest Mediterranean). Mar Ecol Prog Ser 160: 121-134

Tudela S, Palomera I, Quílez G (2002) Feeding of anchovy Engraulis encrasicolus larvae in the north-west Mediterranean. J Mar Biol Assoc UK 82:349-350

van der Lingen CD (1998) Nitrogen excretion and absorption efficiencies of sardine Sardinops sagax fed phytoplankton and zooplankton diets. Mar Ecol Prog Ser 175: $67-76$

van der Lingen CD, Miller TW (2011) Trophic dynamics of pelagic nekton in the southern Benguela Current Ecosystem: calibrating trophic models with stable isotope analysis. In: Omori J, Guo X, Yoshie N, Fujii N, Handoh IC, Isobe A, Tanabe S (eds) Interdisciplinary studies on environmental chemistry-marine environmental modeling and analysis. TERRAPUB, Tokyo, p 85-94

van der Lingen $C D$, Bertrand A, Bode A, Brodeur R and others (2009) Trophic dynamics, Chap 7. In: Checkley DM, Roy C, Alheit J, Oozeki Y (eds) Climate change and small pelagic fish. GLOBEC Project Office, Plymouth, p 112-157

> Vander Zanden MJ, Casselman JM, Rasmussen JB (1999) Stable isotope evidence for the food web consequences of species invasions in lakes. Nature 401:464-467

Vanderklift MA, Ponsard S (2003) Sources of variation in consumer-diet $\delta^{15} \mathrm{~N}$ enrichment: a meta-analysis. Oecologia 136:169-182

Submitted: September 16, 2011; Accepted: April 5, 2012 Proofs received from author(s): July 9, 2012 